\title{
TINJAUAN YURIDIS UU NO. 15 TAHUN 2001 TENTANG MEREK : SISI LAIN KELEMAHAN SISTEM FIRST TO FILE DALAM PERLINDUNGAN HUKUM ATAS MEREK SEBAGAI BAGIAN DARI HAK ATAS KEKAYAAN INTELEKTUAL (HaKI)
}

\author{
Oksidelfa Yanto \\ Fakultas Hukum Universitas Pamulang, Tangerang - Banten \\ Email : adeng_delfaa@yahoo.com
}

\begin{abstract}
If William Shakespeare were still alive, he would consider taking his quote "What's in a name?" back. In this modern era, on the other hand, names have great significance. A name is not only parents' prayers but also their hope. One is named after Budiman-virtuous-simply because the parents expect him to grow as a virtuous person. Similarly, one who is named Sholeh is expected to be pious, religious, or spiritual.

In business settings, a name plays a significant role in the success of a business. For entrepreneurs, a name is a brand which is unquestionably a trademark of their products or services. Therefore, a name or brand is of great value for it is the name which identifies a particular product, along with its image, qualities and benefits. Such identification or distinction-as stipulated in Article 1 Paragraph 1 of Law No.15/2001 on Trademark-may refer to signs, pictures, colors, numbers, words, or combination of said elements.

In practice, business people make use of trademarks to build brand loyalty. Some others, however, regrettably manipulate such loyalty by piggybacking, that is, by using registered or famous brands for their own advantage. Such a practice in fact violates the standard procedure of acquiring a brand for trademark of products or services.
\end{abstract}

Keywords : brand, first to file, intellectual property rights

\begin{abstract}
Abstrak
Andai kata William Shakespeare masih hidup, dia akan menarik kembali pernyataannya yang berbunyi "apalah arti sebuah nama", karena saat ini nama bagi seseorang sangatlah penting. Nama adalah doa, nama adalah sebuah harapan. Seseorang yang bernama Budiman tentunya diharapkan menjadi anak yang berbudi luhur oleh kedua orang tuanya. Begitu juga dengan Soleh, yang diharapkan kelak menjadi orang yang soleh.

Di dunia bisnis dan perdagangan, nama juga berpengaruh untuk kemajuan suatu usaha. Nama pengusaha adalah merek, bisa dijadikan merek dagang atau merek jasa. Sesungguhnya, bagi pengusaha, merek bukanlah sekedar nama tanpa arti, tapi merek adalah produk bernilai tinggi. Karena suatu merek dapat menghasilkan
\end{abstract}


keuntungan yang berbeda dibandingkan dengan merek lain. Ciri khas perusahaan, misalnya melaui simbol, gambar, warna, angka, kata-kata atau kombinasi dari seluruh elemen tersebut seperti tercantum dalam pasal 1, ayat 1, UU no. 15 tahun 2001 tentang Merek.

Meskipun pada prakteknya cara ini kerap digunakan dalam membangun suatu merek yang melekat pada konsumen walaupun tidak sehat, yaitu dengan cara "menumpang" nama pada suatu merek yang sudah terdaftar atau terkenal di pasaran. Cara seperti ini melanggar prosedur akuisisi suatu merek demi tujuan perdagangan dan jasa.

Kata Kunci : Merek, first to file, Hak Kekayaan Intelektual

\section{A. PENDAHULUAN}

Seperti diungkapkan Wolfhard, HaKI kian merupakan bagian integral dalam kebijakan ekonomi, khususnya kebijakan perdagangan. ${ }^{1}$ Hak atas Kekayaan Intelektual (HaKI) atau Hak Milik Intelektual (HMI) adalah padanan kata yang biasa digunakan untuk Intellectual Property Rights (IPR). Objek yang diatur dalam HaKI adalah karya-karya yang timbul atau lahir karena kemampuan intelektual manusia.

Dengan pemahaman tentang konsep dasar dari pada HaKI yang lahir karena kemampuan intelektual manusia tersebut, maka HaKI menjadi penting untuk diketahui. Disamping itu, HaKI juga penting untuk diajarkan demi program pembangunan di bidang pendidikan. Pengajaran HaKI kurang maksiml bila hanya memberikan pokok-pokok pengaturan dalam peraturan perundang-undangan. Karena cenderung mekanik sifatnya dan hanya menghasilkan pemahaman sisi teknik formal. Dari itulah, pemahaman tentang HaKI perlu dipahami dengan konsep dasar. Misalnya, dengan memahami pokok-pokok yang terkandung dalam peraturan nasional dan internasional bidang HaKI. ${ }^{2}$

Salah satu HaKI yang harus dipelajari dan dipahami adalah merek. Merek adalah karya yang dihasilkan melalui kemampuan intelektual manusia. Disamping merek ada juga bagian HaKI yang lain yaitu, hak cipta, paten, disain industry,

\footnotetext{
${ }^{1}$ Wolfhard.Eric, International Trade in Intellectual Proerty : The Emirging GATT reginer University on Toronto Facultyt of Law Review, Vol 49 Winter (1991) : h: 107

${ }^{2}$ Bambang Kesowo, Pengajaran HAKI dan Pembangunan Bangsa yang Berbasis IPTEK, merupakan bagian dari Makalah disajikan dalam National Seminar on Intellectual Property Education, Fakultas Hukum UGM_WIPO, Yogyakarta, 16-21 April 2007.
} 
rahasia dagang. Namun dalam praktek masih sangat kurang sekali penghargaan masyarakat atas HaKI tersebut. Apalagi mereka yang memiliki tingkat pendidikan dibawah rata-rata. Sehingga tidak heran tingkat kesadaran sosial kewajiban untuk menghormati HaKI orang lain menjadi kurang. ${ }^{3}$

Merek merupakan salah satu bagian penting dalam hukum HaKI. Merek merupakan kekayaan industri yang termasuk kekayaan intelektual. Secara umum merek dapat berupa nama, kata, logo, lambang, desain, warna, gambar, atau kombinasi dua atau lebih unsur tersebut. Merek merupakan hal yang sangat penting dalam dunia bisnis. ${ }^{4}$

Sebagai bagian dari Hukum hak atas kekayaan intelektual maka suatu merek jelas akan dilindungi dalam penggunaan dan pemakaiannya. Untuk dapat dilindunginya suatu merek, maka merek tersebut terlebih dahulu harus didaftarkan. Pendaftaran tersebut menjadi penting untuk mendapatkan hak atas merek tersebut. Hak atas merek adalah hak eksklusif yang diberikan negara kepada pemilik merek yang terdaftar dalam "daftar umum merek" untuk jangka waktu tertentu.

Setelah suatu merek didaftarkan kemudian pemilik merek menggunakan sendiri dan memberikan izin merek tersebut kepada pihak lain untuk digunakan sebagaimana yang ditegaskan dalam Pasal 3 Undang-Undang No. 15 Tahun 2001 tentang merek yang berbunyi; pemilik merek mempunyai hak menggunakan sendiri merek tersebut dan hak memberikan izin kepada orang lain untuk menggunakan merek tersebut. Dengan demikian jelaslah bawa perlindungan hukum terhadap merek diberikan melalui proses pendaftaran, baik perlindungan untuk menggunakan sendiri atau perlindungan dalam hal memberikan izin kepada pihak lain. ${ }^{5}$

\footnotetext{
${ }^{3}$ Prayudi Setiadharma, Mari Mengenal HaKI, Jakarta: Goodfaith Production, 2010, hal.7.

${ }^{4}$ Merek, sebagai hak milik yang timbul atau lahir karena kemampuan intelektual manusia melalui daya cipta dan karsa, yang untuk menghasilkannya memerlukan pengorbanan tenaga, pikiran, waktu dan biaya, menjadikan karya yang dihasilkan mempunyai nilai. Nilai ekonomi yang melekat pada hak milik itu menimbulkan konsepsi kekayaan (property). Dengan konsep kekayaan, maka HKI memberikan perlindungan hukum terhadap hak atas merek. Pemilik hak perlu dipertahankan eksistensinya terhadap siapa saja yang menggunakannya tanpa ijin. Merek tanpa sertifikat pendaftaran tidak akan dilindungi oleh undang-undang HKI. (http://atmajaya.ac.id).

${ }^{5}$ Terdapat dua bentuk seistem perlindungan merek tyaitu sistem konstitutif dan first adalah hak atas merek diberikan kepada penfataran merek pertama..
} 
Sistem pendaftar pertama disebut juga first to file principle. Artinya, merek yang didaftar adalah yang memenuhi syarat dan sebagai yang pertama. Kemudian sistem pendaftaran berubah menjadi first to file. Artinya, dalam sistim hukum merek. Indonesia menganut dan menerapkan sistim first to file, yang berarti, siapa yang mendaftar lebih dahulu, maka dialah yang berhak. Namun demikian sistem first to file tersebut memiliki kelemahan yang berarti.

Berdasarkan hal tersebut, maka tulisan ini pada dasarnya akan mencoba mengulas mengenai apakah merek tersebut. Bagaimana perlindungan hukum atas merek yang sudah didaftarkan serta bagaimanakah kelemahan sistem first to file dalam pendaftaran suatu merek?

Dalam penulisan artikel ini penulis menggunakan metode penelitian yuridis normatif, Dalam hal ini yaitu penelitian terhadap bahan-bahan hukum yang ada relefansinya dengan hukum hak atas kekayaan intelektual khususnya yang berkaitan dengan merek. Data-data diperoleh melalui studi kepustakaan dan selanjutnya dianalisis secara kualitatif.

\section{B. PEMBAHASAN}

\section{Pentingnya Sertifikat Hak Merek}

Hak atas merek adalah hak eksklusif yang diberikan negara kepada pemilik merek yang terdaftar dalam Daftar Umum Merek untuk jangka waktu tertentu. Kemudian pemilik merek menggunakan sendiri merek tersebut atau memberi ijin kepada seseorang atau beberapa orang secara bersama-sama atau badan hukum untuk menggunakannya.

Dengan demikian apabila seseorang atau suatu badan telah mendaftar suatu merek, maka pihak lain tidak boleh lagi mendaftar dengan merek yang sama. Kalau ingin juga mendaftar atau ingin memakai merek yang sama, maka pihak lainnya tersebut harus terlebih dahulu meminta izin kepada si pemilik merek pertama.

Hal ini sesuai dengan sistem hukum merek yang dianut Indonesia yaitu first to file. Artinya, siapa yang lebih dahulu mendaftar atau memperoleh sertifikat 
merek, dialah yang berhak atas merek tersebut. Pihak lain tidak dibolehkan mendaftarkan suatu merek dengan nama yang sama. ${ }^{6}$

Banyak orang Indonesia mendaftarkan merek $^{7}$ meski tidak berbisnis. Yang penting mereknya dulu, usahanya belakangan. Bahkan, ada orang yang berprofesi sebagai pedagang merek terutama merek-merek yang mereka dapatkan dari luar negeri. Hingga Februari 2010 saja, di Indonesia, permohonan pendaftaran merek baru yang masuk mencapai 7.333, sedangkan permohonan perpanjangan pendaftaran berjumlah 1.697. Tiap tahun kecenderungan jumlah pendaftaran merek terus meningkat. Pada 2008 hingga 2009, misalnya, angka pendaftaran mencapai 45 ribu. Dua tahun sebelumnya menginjak jumlah 40 ribuan saja ${ }^{8}$.

Pada masyarakat kelas dunia, China sudah menjadi tujuan bagi pengusaha di seluruh dunia untuk mendaftarkan merek dagang/jasa mereka. Pilihan China sebagai prioritas utama mendaftarkan merek antara lain didasarkan atas perkembangan dan potensi pasarnya yang sangat besar. Menurut data yang dirilis oleh World Intellectual Property Organization (WIPO) pada 4 April 2011, selama tahun 2010, organisasi hak kekayaan intelektual sedunia itu menerima permohonan pendaftaran merek secara internasional berdasarkan Madrid System sebanyak 39.687, sedangkan tahun 2009 hanya ada 35.195. Menurut data WIPO, Jerman menempati posisi paling atas dari segi jumlah permohonan pendaftaran merek yaitu sebanyak 5,006 atau mewakili 12,6\% dari total pendaftaran. Negara di Eropa tercatat sebagia ranking kedua dengan jumlah permohonan 4.707 atau meningkat 26,9\% bila dibandingkan tahun 2009, sedangkan permohonan pendaftaran dari Amerika Serikat berada di posisi ketiga dengan permohonan 4.147 atau $10,4 \%$ dari total pendaftaran.

Jumlah pendaftaran merek ke WIPO sebanyak 39.687 itu berasal dari 85 negara anggota yang sudah meratifikasi konvensi Protokol Madrid. Indonesia hingga kini belum lagi meratifikasi konvensi tersebut, sehingga bila ada

\footnotetext{
${ }^{6}$ Baca juga lebih jauh, Haris Munandar, Mari Mengenal HaKI, Erlangga, 2009.

${ }^{7}$ Ketentuan mengenai syarat dan tata cara Permohonan Pendaftaran Merek diatur dalam Pasal 7 sampai dengan Pasal 10 Undang-undang Nomor 15 Tahun 2001 tentang Merek

${ }^{8}$ Hukum Online, Biaya Siluman di Balik Pendaftaran Merek, Selasa, 27 April 2007.
} 
perusahaan asal Indonesia yang ingin menggunakan fasilitas pendaftaran merek secara internasional melalui WIPO tersebut belum bisa dilaksanakan. Bila ada perushaan Indonesia ingin medaftarkan merek dagang / merek jasa mereka ke luar negeri, maka perusahaan tersebut harus mendaftarkan langsung ke masing-masing negara yang dituju.

Dari jumlah permohanan pendaftan merek sebanyak 39.687 tersebut, sebanyak 16.143 pemohonan atau 5,4\% menunjuk negara China sebagai tujuan pendaftaran pertama, diikuti Eropa (14.604), Amerika Serikat (15.252), Rusia (14.252), Swiss (12.469), Jepang (11.124), Jepang (11.124), Australia (9.222), Korea Selatan (8.336), Ukrania (8.288) dan Turki (8.210). Tingginya minat perusahaan mendaftarkan merek mereka di China menunjukan bahwa banyak pengusaha di dunia ingin menjalankan bisnis di China, sehingga sebelum memasuki negara tersebut, mereka memlih lebih dahulu mendaftarkan merek dagang/jasa mereka untuk mendapatkan perlindungan hukum. Selain China, negara di kawasan Asia yang menjadi tujuan pendaftaran merek adalah Jepang dan Korea Selatan dan Singapura. ${ }^{9}$

Berdasarkan hal tersebut diatas, membicarakan soal merek tidak dapat dihindari adanya hak atas merek yang menjadi obyek dari kekayaan intelektual dengan sistem pendaftaran. Hak atas sebuah merek harus didahului dengan pendaftaran. Dengan adanya sistem pendaftaran merek, maka seorang pemilik merek akan mendapatkan sertifikat merek.

Keberadaan sertifikat ini menjadi penting dalam hukum Hak atas Kekayaan Intelektual (HaKI). Sebab hukum HaKI hanya akan memberikan hak atas merek kepada pemilik merek yang mereknya telah didaftar menurut undang-undang yang berlaku sehingga memperoleh sertifikat. Bagaimana dengan merek-merek terkenal yang tidak / belum didaftar di suatu negara? Apakah merek tersebut akan mendapatkan perlindungan di negara lain jika merek tersebut tidak didaftarkan dinegara tersebut? Terutama merek-merek terkenal? Banyak negara yang tidak memberikan perlindungan atas sebuah merek. Jika merek terdaftar disuatu negara, maka merek tersebut hanya dilindungi di negara dimana merek itu didaftar.

\footnotetext{
${ }^{9}$ www.patenindonesia.com
} 
Seseorang dapat mendaftarkan merek yang sama dinegara lain. Hal ini bertolak belakang dengan prinsip pendaftaran atas sebuah mereka yaitu first to file. Siapa yang pertama mendaftar dialah yang berhak atas merek tersebut. Namun kenyataannya orang boleh mendaftarkan merek yang sama yang penting berbeda negaranya.

\section{Pengertian Merek}

Pengertian merek menurut David A. Aaker adalah nama dan atau simbol yang bersifat membedakan (seperti sebuah logo, cap atau kemasan) dengan maksud mengidentifikasi barang atau jasa dari seorang penjual atau sebuah kelompok penjual tertentu. Dengan demikian suatu merek membedakannya dari barang dan jasa yang dihasilkan oleh kompetitor. Sedangkan menurut William J. Stanton merek adalah nama, istilah, simbol atau desain khusus atau beberapa kombinasi unsur - unsur ini yang dirancang untuk mengidentifikasikan barang atau jasa yang ditawarkan oleh penjual ${ }^{10}$.

Sementara itu, Merek menurut Pasal 1 ayat (1) Undang-Undang (UU) No.

15 Tahun 2001 tentang Merek adalah

"tanda atau simbol yang dapat berupa gambar, nama, kata, huruf - huruf, angka-angka, susunan warna atau kombinasi dari unsur - unsur tersebut yang memiliki daya pembeda dan digunakan dalam kegiatan perdagangan barang atau jasa".

Ini terlihat misalnya pada kemasan rokok Djie Sam Soe. Ada kumpulan kata, simbol beberapa bintang, angka 234. Sedangkan pengertian Merek sebagaimana diatur dalam Pasal 15 ayat (1) TRIPs Agreement adalah sebagai berikut:

"Any sign or any combination of signs, capable of distinguishing, the goods of services of one undertaking from those of other undertakings, shall be capable of constituting a trademark. Suchs signs, in particular words including personal names, letters, numerals, figurative elements and combinations of colours as well as any combination of such signs, shall be eligible for registration as trademark. Where signs are not inherently capable of distinguishing the relevant goods or services, members may make registrability depend on distinctiveness acquired through use.

\footnotetext{
${ }^{10}$ Tribun Timur, Pengertian Merek 10 Desember 2009.
} 
Members may require, as a condition of registration, that signs be visually perceptible"

"Setiap tanda, atau kombinasi dari beberapa tanda, yang mampu membedakan barang atau jasa satu dari yang lain, dapat membentuk merek. Tanda - tanda tersebut, terutama yang berupa kata-kata termasuk nama orang, huruf, angka, unsur figuratif dan kombinasi dari beberapa warna, atau kombinasi warna - warna tersebut, dapat didaftarkan sebagai merek. Dalam hal suatu tanda tidak dapat membedakan secara jelas barang atau jasa satu dengan yang lain, Negara anggota dapat mendasarkan keberadaan daya pembeda tanda-tanda tersebut melalui penggunaannya, sebagai syarat bagi pendaftarannya. Negara anggota dapat menetapkan persyaratan bahwa tanda-tanda tersebut harus dapat dikenali secara visual sebagai syarat bagi pendaftaran suatu merek".

Berdasarkan pendapat tersebut diatas, dapat disimpulkan bahwa bahwa merek merupakan suatu tanda yang dapat menunjukkan identitas barang atau jasa, yang yang menjadi pembeda suatu barang atau jasa dengan barang atau jasa lainnya dihasilkan oleh seseorang, beberapa orang atau badan hukum dengan barang atau jasa yang sejenis milik orang lain, memiliki kekuatan perbedaan yang cukup, yang dipakai dalam produksi dan perdagangan Merek adalah suatu tanda, tetapi agar tanda tersebut dapat diterima oleh merek, harus memiliki daya pembeda, ${ }^{11}$ hal ini disebabkan pendaftaran merek, berkaitan dengan pemberian hak eksklusif yang diberikan oleh negara atas nama atau simbol terhadap suatu pelaku usaha.

Untuk mempunyai daya pembeda, merek yang bersangkutan harus dapat memberikan penentuan atau "individuali sering" dari barang yang bersangkutan. ${ }^{12}$ Undang-Undang Nomor 15 Tahun 2001 tidak mengatur lebih lanjut apa yang disebut gambar, nama, kata, huruf, angkaangka dan susunan warna. Namun demikian Undang-Undang, dalam hal ini pasal 5 memberikan batasan bahwa gambar, nama, kata, huruf, angka atau susunan warna yang dijadikan merek harus memenuhi syarat : a. Tidak bertentangan dengan peraturan perundangan yang berlaku, moralitas agama, kesusilaan atau ketertiban umum; b. Memiliki daya

\footnotetext{
${ }^{11}$ Suyud Margono dan Lingginus Hadi, Pembaharuan Perlindungan Hukum Merek, Novirindo Pustaka Mandiri, Jakarta, 2002, hlm. 27.

${ }^{12} 42$ Sudargo Gautama dan Rizawanto Winata, Hukum Merek Indonesia, PT. Citra Aditya Bakti, Bandung, 1993, hal.40.
} 
pembeda; c. Bukan menjadi milik umum; d. Bukan keterangan yang berkaitan dengan barang atau jasa yang dimohonkan;

Kalau kita perhatikan definisi merek menurut UU di atas, dapat diketahui unsur-unsur apa saja yang harus dipenuhi dalam menentukan sesuatu sebagai merek. Hal ini dapat kita lihat berdasarkan isi pasal tersebut yaitu tanda atau simbol, yang berupa; Pertama. Gambar, misalnya merek yang menggunakan gambar gajah, hal ini bisa dilihat pada merek sarung Gajah Duduk. Kedua. Nama. Merek yang menggunakan nama orang untuk merek parfum misalnya Charlie, atau coklat Van Houten dan lain-lain. Ketiga. Kata. Merek yang menggunakan kata, misalnya Family untuk merek kue. Keempat. Angka. Misalnya, angka 555 digunakan sebagai merek rokok. Kelima. Huruf. Misalnya kumpulan huruf-huruf. Merek $A B C$ untuk macam-macam produk makanan dan minuman. Keenam. Susunan warna. Susunan warna merah, hijau, kuning, biru. Misalnya warna pelangi yang digunakan untuk merek pensil berwarna. Ketujuh. Kombinasi dari itu semua dari nomor (satu) - (enam). Misalnya pada kemasan rokok Djie Sam Soe. Ada kumpulan kata, simbol beberapa bintang, angka 234.

Dari beberapa defenisi yang dikemukakan diatas, maka dapatlah ditarik sebuah kesimpulan bahwa fungsi merek tersebut adalah

Pertama, sebagai tanda pengenal untuk membedakan hasil produksi yang dihasilkan seseorang atau beberapa orang secara bersama-sama atau badan hukum dengan produksi seseorang atau beberapa orang atau badan hukum lain.

Kedua, sebagai alat promosi, sehingga mempromosikan hasil produksinya cukup dengan menyabut mereknya. Ketiga, sebagai jaminan atas mutu barang nya ${ }^{13}$.

\footnotetext{
${ }^{13}$ Selain itu Merek juga digunakan sebagai nama atau simbol pada obyek barang / jasa juga digunakan sebagai sarana promosi. Tanpa merek pengusaha tidak dapat mempromosikan barang / jasanya kepada masyarakat luas dan maksimal. Dan, masyarakat tidak dapat membedakan mutu barang/jasa satu dengan lainnya. Selain itu, merek juga dapat mencegah orang berbuat curang dan bersaing secara tidak sehat. Meskipun persaingan dalam dunia usaha adalah hal biasa, namun merek dapat mencegah terjadinya hal-hal yang dapat merugikan pihak lain. Melalui merek asal usul barang pun bisa dideteksi. Artinya, dapat diketahui suatu barang berasal dari daerah mana. Misalnya, orang Perancis penggemar kopi Kintamani. Lihat lebih jauh AB Susanto dan Himawan Wijanorko, Membangun Merek Unggul dan Organisasi Pendukungnya, Jakarta : Mizan Pustaka, 2008, hlm 5-6.
} 


\section{Perkembangan Peraturan hukum Perlindungan Merek di Indonesia}

Persoalan merek sebenarnya bukan hal baru bagi Indonesia. Dalam sejarah perundang-undangan merek, dapat diketahui bahwa pada masa kolonial Belanda berlaku Reglemen Industriele Eigendom (RIE) yang dimuat dalam Staatblad 1912 Nomor 545 jo Staatblad 1913 Nomor 214.

Pada masa penjajahan Jepang, dikeluarkan peraturan merek, yang disebut Osamu Seire Nomor 30 tentang Pendaftaran cap dagang yang mulai berlaku tanggal 1 bulan 9 Syowa (tahun Jepang 2603). Setelah Indonesia Merdeka (17 Agustus 1945), peraturan tersebut masih diberlakukan berdasarkan Pasal II Aturan Peralihan Undang-Undang Dasar 1945.

Selanjutnya, sejak era kebijakan ekonomi terbuka pada Tahun 1961 diberlakukan Undang-Undang Nomor 21 Tahun 1961 tentang Merek Perusahaan dan Merek Perniagaan yang menggantikan peraturan warisan kolonial Belanda yang sudah dianggap tidak memadai, meskipun Undang-Undang tersebut pada dasarnya mempunyai banyak kesamaan dengan produk hukum kolonial Belanda tersebut.

Tahun 1992 UU Merek baru diundangkan dan berlaku mulai tanggal 1 April 1993, mengantikan UU Merek tahun 1961. Dengan adanya 1 April 1993, mengantikan UU Merek tahun 1961. Dengan adanya UU baru tersebut, surat keputusan administrasi yang terkait dengan prosedur pendaftaran merekpun dibuat. Berkaitan dengan kepentingan reformasinUU Merek, Indonesia turut serta meratifikasi perjanjian Internasional Merek WIPO.

Tahun 1997, UU Merek tahun 1992 diubah dengan mempertimbangkan pasal-pasal dari perjanjian Internasional Tentang Aspek-Aspek yang dikaitkan dengan perdagangan dari Hak Kekayaan Intelektual (TRIPs) - GATT.

Pasal-pasal tersebut memuat perlindungan atas indikasi asal geografis. UU tersebut juga mengubah ketentuan dalam UU sebelumnya dimana pengguna 
merek pertama di Indonesia berhak untuk mendaftarkan merek tersebut sebagai merek. $^{14}$.

Perkembangan selanjutnya, Undang-Undang Merek telah mengalami perubahan, baik diganti maupun direvisi karena nilainya sudah tidak sesuai dengan perkembangan keadaan dan kebutuhan. Pada akhirnya, pada tahun 2001 diundangkanlah Undang - Undang Nomor 15 Tahun 2001 tentang Merek. Undang - Undang Merek ini merupakan hukum yang mengatur perlindungan merek di Indonesia. Undang - Undang tersebut merupakan produk hukum terbaru di bidang merek sebagai respon untuk menyesuaikan perlindungan merek di Indonesia dengan standar internasional yang termuat dalam Pasal 15 Perjanjian TRIPs sebagai pengganti UU sebelumnya yaitu Undang - Undang Nomor 14 tahun 1997 tentang Perubahan Atas Undang-Undang Nomor 19 tahun 1992 tentang Merek ${ }^{15}$.

\section{Hak Eksklusis dalam Merek}

Dalam merek dikenal adanya hak eksklusif sebagaimana dinyatakan dalam Pasal 3 Undang - Undang Nomor 15 Tahun 2001 tentang Merek, yaitu hak eksklusif yang diberikan negara kepada pemilik merek yang terdaftar dalam daftar umum merek untuk jangka waktu tertentu untuk menggunakan sendiri merek tersebut atau memberikan izin kepada orang lain untuk menggunakannya.

Secara umum hak eksklusif dapat didefinisikan sebagai "hak yang memberi jaminan perlindungan hukum kepada pemilik merek, dan merupakan pemilik satu - satunya yang berhak memakai dan mempergunakan serta melarang siapa saja untuk memiliki dan mempergunakannya”. Lebih jauh dalam Pasal 3 Undang Undang Nomor 15 Tahun 2001 disebutkan, hak merek diberikan kepada pemilik merek terdaftar, dengan demikian jelas bahwa sistem merek yang dipakai di Indonesia adalah sistem konstitutif (aktif) sehingga pemilik merek terdaftar adalah sebagai pemegang hak merek. Pemilik merek terdaftar sebagai pemegang merek

\footnotetext{
${ }^{14}$ Hak Atas Kekayaan Intelektual Suatu Pengantar, Bandung : Alumni, 2002, hal 132. Baca juga lebih jauh, Tim Lindsey, Eddy damian, Simon Butt, Tomi suryo Utomo, Hak Atas Kekayaan Intelektual Suatu Pengantar, Bandung : Alumni, 2006.

${ }^{15}$ Beberapa perubahan penting yang tercantum dalam UU No. 15 Tahunn 2001 tersebut adalah penetapan sementara pengadilan, perubahan delik biasa menjadi delik aduan, peran Pengadilan Niaga dalam memutuskan sengketa merek, kemungkinan menggunakan alternative penyelesaian sengketa dan ketentuan pidana yang diperberat.
} 
menggunakan merek itu sendiri atau memberi ijin pihak lain menggunakannya. Lebih lanjut dalam pasal 40 Undang - Undang Merek Nomor 15 Tahun 2001 dinyatakan bahwa hak merek dapat dialihkan haknya menurut ketentuan Undang Undang.

Menyangkut fungsi merek sebagaimana dinyatakan dalam Pasal 3 Undang Undang Nomor 15 Tahun 2001 tentang Merek adalah sebagai alat pembeda barang atau jasa. Berkenaan dengan hal tersebut merek dilihat dari daya pembedanya dibagi dalam dua kategori, yaitu kategori pertama adalah merek yang lemah daya pembedanya karena sifatnya yang deskriptif, dan kategori kedua adalah merek yang kuat daya pembedanya karena merupakan hasil imajinasi. Dengan demikian, hak eksklusif memuat dua hal, yaitu, pertama, menggunakan sendiri merek tersebut, dan kedua, memberi ijin kepada pihak lain menggunakan merek tersebut.

Hak eksklusif bukan merupakan monopoli yang dilarang sebagai persaingan tidak sehat sebagaimana dimaksud dalam Undang - Undang Nomor 5 Tahun 1999 tentang Monopoli dan Persaingan Tidak Sehat, tetapi justru merupakan hak yang bersifat khusus dalam rangka memberi penghormatan dan insentif pengembangan daya intelektual untuk sebuah persaingan sehat dan kesejahteraan masyarakat.

\section{Sistem Pendaftaran Merek}

Agar suatu merek diakui keberadaannya dan mendapatkan perlindungan dari segi hukum, maka merek tersebut harus didaftarkan ${ }^{16}$. Pendaftaran merek berguna sebagai alat bukti yang sah atas merek terdaftar, pendaftaran merek juga berguna sebagai dasar penolakan terhadap merek yang sama keseluruhannya atau sama pada pokoknya ${ }^{17}$ yang dimohonkan oleh orang lain untuk barang atau jasa sejenis. Dan, sebagai dasar mencegah orang lain memakai merek yang sama pada

\footnotetext{
${ }^{16} \mathrm{Hal}$ - hal yang menyebabkan suatu merek tidak dapat didaftarkan adalah : pertama, didaftarkan oleh pemohon yang beretikad tidak baik; kedua, bertentangan dengan peraturan perundang - undangan yang berlaku, moralitas keagamaan, kesusilaan, atau ketertiban umum; ketiag, tidak memiliki daya pembeda; kempat, telah menjadi milik umum; atau kelima, merupakan keterangan atau berkaitan dengan barang atau jasa yang dimohonkan pendaftarannya. (pasal $4 \&$ pasal 5 uum)

${ }^{17}$ Sama pada pokoknya dapat diartikan kemiripan yang disebabkan oleh adanya unsur - unsur yang menonjol antara merek yang satu dengan yang lain yang dapat menimbulkan kesan adanya persamaan baik menge nai bentuk, cara penempatan, cara penulisan atau kombinasi antara unsur-unsur atau persamaan bunyi ucapan yang terdapat dalam merek tsb
} 
pokoknya atau secara keseluruhan dalam peredaran barang atau jasa. ${ }^{18}$ Sejatinya, pendaftaran merek bertujuan untuk memperoleh kepastian hukum dan perlindungan hukum terhadap hak atas merek. Pedaftaran merek dilakukan pada Direktorat Jendral Hak Kekayaan Intelektual. Direktorat Jendral HKI adalah instansi pendaftaran merek yang ditugaskan untuk mendaftarkan merek yang dimohonkan pendaftarannya oleh pemilik merek. Pendaftaran merek dilakukan dengan memenuhi syarat - syarat sebagaimana telah ditentukan oleh UU No. 15 Tahun 2001.

Dengan demikian maka perlindungan hukum terhadap merek diberikan melalui proses pendaftaran. ${ }^{19}$ Permohonan pendaftaran merek dapat dilakukan oleh orang perseorangan, badan hukum, beberapa orang / badan hukum (pemilik bersama merek kolektif).

Undang - Undang No. 15 Tahun 2001 tentang Merek menerapkan sistem konstitutif. Artinya, hak atas merek diperoleh karena proses pendaftaran, yaitu pendaftar merek pertama yang berhak atas merek.

Dalam pendaftaran suatu merek dikenal dua macam sistem pendaftaran. Yaitu sistem konstitutif ${ }^{20}$ dan deklaratif. Sistem deklaratif adalah sistem pendaftaran yang hanya menimbulkan dugaan adanya hak sebagai pemakai pertama pada merek bersangkutan. Sistem deklaratif dianggap kurang menjamin

\footnotetext{
${ }^{18}$ Pasal 90 UU Merek menegaskan barang siapa yang dengan sengaja dan tanpa hak menggunakan merek yang sama pada keseluruhannyanya dengan merek terdaftar pihak lain untuk barang dan/atau atau jasa yang sejenis yang diproduksi dan atau diperdagangkan, dipidana dengan pidana penjara paling lama 5 (lima) tahun dan / atau denda paling banyak Rp 1.000.000.000,00 (satu miliar rupiah). Selanjutnya, Pasal 91 memberikan ancaman pidana penjara paling lama 4 (empat) tahun dan / atau denda paling banyak Rp 800,000.000,00 (delapan ratus puluh juta) bagi barang siapa yang sengaja dan tanpa hak menggunakan merek yang sama pada pokoknya dengan merek terdaftar milik pihak lain untuk barang dan / atau atau jasa yang sejenis yang diproduksi dan atau diperdagangkan jjatau badan hukum lain. Dengan demikian, sanksi pidananya juga didasarkan pada pelanggaran pidananya dan pelanggaran merek untuk barang atau jasa yang sejenis.

${ }^{19}$ Suatu merek yang sudah terdaftar dan bersertifikat dilindungi selama 10 tahun dan berlaku surut sejak tanggal penerimaan pendaftaran merek.

${ }^{20}$ Pada prinsipnya belakangan semua Negara Asean telah menganut system pendaftaran konstitutif. Penggunaan system konstitutif juga diimbangi dengan ketentuan yang dapat menjamin segi - segi keadilan bagi masyarakat antara lain yaitu pada masa pengumuman permintaan pendaftaran merek dimungkinkan pemilik merek yang tidak terdaftar yang telah menggunakan sebagai pemekai merek pertama untuk mengajukan keberatan. Lihat lebih jauh Taryana Soenandar, Perlindungan HaKI dinegara-negara Asean, Jakarta: Sinar Grafika, hal. 65-70.
} 
kepastian hukum dibandingkan dengan sistem konstitutif berdasarkan pendaftaran pertama yang lebih memberikan perlindungan hukum ${ }^{21}$.

Sistem pendaftar pertama disebut juga first to file principle. Artinya, merek yang didaftar adalah yang memenuhi syarat dan sebagai yang pertama. Tidak semua merek dapat didaftarkan. Merek tidak dapat didaftar atas dasar permohonan yang diajukan oleh pemohon yang beretikad tidak baik. Pemohon beretikad tidak baik adalah pemohon yang mendaftarkan mereknya secara tidak layak dan tidak jujur, ada niat tersembunyi misalnya membonceng, meniru, atau menjiplak ketenaran menimbulkan persaingan tidak sehat dan mengecohkan atau menyesatkan konsumen. Yang dapat mendaftarkan merek adalah orang atau badan hukum ${ }^{22}$.

Kemudian sistem pendaftaran berubah menjadi first to file. Artinya, dalam sistim hukum merek. Indonesia menganut dan menerapkan sistim first to file, yang berarti, siapa yang mendaftar lebih dahulu, maka dialah yang berhak. Sebagai contoh, Pak Ahmad menggunakan merek untuk suatu produk tertentu dipasar domestik dan produk tersebut juga di ekspor ke mancanegara, dan menggunakan merek baru. Dalam kasus ini sangat dianjurkan untuk mendaftarkan mereknya terlebih dahulu sebagai usaha proteksi di Indonesia, kemudian dimintakan bukti prioritas selama jangka waktu 6 bulan. Jika Pak Ahmad ingin mereknya terproteksi di Amerika atau Jepang, maka pak Ahmad dapat mengajukan permintaan pendaftaran merek di negara yang dituju melalui Community Trademark. Misalnya menggunakan hak prioritas kemudian mengajukan pada tanggal 10 Januari 2008 dan mencantumkan sampai dengan 10 Juli 2008 batas akhir berlakunya hak prioritas. Dengan kata lain jika pada tanggal 25 Mei 2008 seseorang di Jepang telah mendaftarkan merek pak Ahmad tersebut, dan pak Ahmad baru mengajukan pendaftaran merek di Jepang pada tanggal 2 Juli 2008, walaupun sistim first to file, tetapi karena pak Ahmad menggunakan hak prioritas dengan mengajukan permintaan pendaftaran merek di Jepang, maka pak Ahmadlah yang berhak.

\footnotetext{
${ }^{21}$ Venantia Sri Hadiarianti, Hak Kekayaan Intelektul: Merek dan Merek Terkenal, Jakarta: Unika Atma Jaya, Edisi Mei-Agustus 2009

${ }^{22}$ Ibid.
} 
Dari contoh tersebut, bila melihat siapa yang lebih dahulu apakah pengusaha Jepang, dan pak Ahmad sesudahnya, tetapi karena pak Ahmad mempunyai hak prioritas dan disertakan dalam dokumen pengajuan pendaftaran merek di Jepang, maka pak Ahmadlah yang akan mendapat perlindungan merek tersebut. Hak prioritas adalah hak yang lebih utama dibandingkan dengan pihak-pihak lain apabila pihak lain mengajukan merek, meskipun pihak lain mendaftarkan terlebih dahulu ${ }^{23}$.

\section{Kelemahan Sistem First To File}

Namun demikian sistem first to file tersebut memiliki kelemahan yang berarti. Dalam sistem pendaftaran first to file, prinsip penerimaan merek adalah first to file, artinya siapapun yang mendaftar lebih dahulu akan diterima pendaftaraannya dengan tidak mempersoalkan apakah si pendaftar benar-benar menggunakan merek tersebut untuk kepentingan usahanya. Beberapa kemungkinan dapat terjadi setelah masuknya pendaftaran pertama, misalnya muncul pendaftar lain yang sebenarnya berkepentingan langsung dengan merek tersebut, sebab pendaftar inilah yang secara riil menggunakan barang tersebut. Dalam hal demikian, pendaftar kemudian (notabene pengguna merek sebenarnya) harus melakukan "Penyelesaian khusus" dengan pendaftar pertama agar pendaftar pertama mau menyerahkan merek tersebut kepada pendaftar kemudian (Purba, 2005). Hal-hal seperti ini lah yang menjadi permasalahan utama dalam sistem pendaftaran konstitutif.Jika kita telaah dengan seksama, maka sistem first to file sebenarnya membuka peluang timbulnya pembajakan suatu merek terutama sekali merek dagang yang dimiliki pihak asing. Artinya, banyak merek terkenal yang didaftarkan oleh bad applicant (pendaftar beritikad buruk). Misalnya, merek Gucci asal Italia yang didompleng dengan merek Guchi, merek Koyo asal Jepang vs Koyo berlogo kelaher, merek Ikea asal Belanda asal vs Ikea 168, merek Sebamed asal Jerman vs Seba dan Ferarri asal Italia vs Ferrari versi Indonesia.

\footnotetext{
${ }^{23}$ Dengan demikian maka fungsi pendaftarann suatu merek adalah pertama, sebagai bukti bagi pemilik yang berhak atas merek yang ter- daftar. Kedua sbg dasar penolakan terhadap merek yang sama keseluruhan / sama pada pokoknya yang dimo honkan oleh pemohon lain utk barang / jasa sejenis. Sebagai dasar utk mencegah orang lain memakai merek yang sama keseluruhan atau sama pada pokoknya dalam peredaran untuk barang / jasa sejenis.
} 
Akhirnya pengadilan membatalkan merek pengusaha lokal yang dinilai mendompleng ketenaran suatu merek.

Contoh lebih spesifiknya begini. Ada sebuah perusahaan yang sudah memiliki merek terkenal di Jepang, namun perusahaan tersebut belum terdaftar di Indonesia. Kondisi ini membuat pihak lain bisa mendaftarkan merek tersebut lebih dahulu ke Ditjen Hak Kekayaan Intelektual Departemen Hukum dan HAM di Indonesia.

Jika suatu saat perusahaan dari Jepang tersebut ingin melakukan ekspansi di pasar Indonesia, maka perusahaan tersebut sudah pasti akan terganjal karena merek dagangnya sudah terdaftar terlebih dahulu atas nama pihak lain yang sebenarnya tidak berhak.

Sesuai dengan UU Merek No. 15 tahun 2001, memang perusahan dari Jepang tadi bisa mengajukan gugatan pembatalan dan penghapusan merek melalui pengadilan. Akan tetapi Direktorat Jenderal Hak atas Kekayaan Intelektual (Ditjen HaKI) sering mengalahkan pihak yang keberatan sekalipun keberatan diajukan oleh pemilik merek terkenal. Dalam kasus ini Ditjen HaKI belum mempertimbangkan alasan merek terkenal dalam oposisi. Ditjen HaKI belum mengakui merek terkenal jika belum ada putusan pengadilan yang menyatakan merek terkenal itu milik pihak yang merasa keberatan.

Dengan demikian, penghapusan tersebut sangat tergantung kepada hakim yang menangani perkara tersebut. Kita tahu, kalau suatu kasus sudah berada di ranah pengadilan, tidak saja banyak uang yang harus dikeluarkan, tapi juga waktu yang harus dihabiskan.

Pihak asing biasanya tidak mau berurusan sampai sejauh itu. Pada akhirnya, banyak dari mereka yang akan kehilangan mereknya. Kalau pihak Jepang ingin juga mengambil hak atas mereknya, maka biasanya pihak lain tadi menawarkan jalan negosiasi. Dengan catatan bahwa perusahaan Jepang harus berani membayar uang sesuai dengan jumlah yang diinginkan oleh pemegang merek yang ada di Indonesia tadi.

Padahal bukankah memang seharusnya, jika bukti kuat dan mereknya terkenal lebih baik perkara diajukan ke pengadilan. Daripada kita beli merek 
dengan harga yang cukup mahal. Tapi malah dalam pengajuan gugatan atas sebuah merek oleh pihak pemilik merek, mereka sering mengalami kekalahan.

Dalam pengajuan gugatan keberatan atas suatu merek, maka ada dua konstruksi gugatan yang dapat diajukan, yakni gugatan pembatalan atau penghapusan merek. Pembatalan merek diajukan lantaran ada persamaan pada pokoknya dengan merek yang sudah lebih dulu terdaftar milik orang lain. Sementara, penghapusan pendaftaran diajukan bila merek terdaftar tidak dipakai.

Sangat banyak perkara yang terkait dengan merek terkenal yang akhirnya merugikan pihak pemilik merek dari negara asalnya. Ambil contoh kasus Prada dan Intel Corp di Indonesia, dan Louis Vuitton di Tiongkok. Dari kasus-kasus tersebut, pemilik merek dari negara asal dikalahkan oleh pengadilan. Pada awalnya, pemilik merek Prada Italy mengajukan gugatan kepada pengusaha Prada Indonesia, karena penggugat merasa bahwa ia adalah pemilik asli dari merek Prada.

Perkara ini berawal pada saat pemilik Prada Italy mencoba mendaftarkan mereknya di Indonesia. Ternyata merek Prada sudah didaftarkan oleh salah satu pengusaha Indonesia. Pada tahap pertama, Pengadilan Niaga menolak gugatan penggugat dengan alasan Indonesia memakai sistem first to file, sehingga pendaftar pertama yang memiliki hak eksklusif dari merek bersangkutan. Hingga tingkat Mahkamah Agung perkara ini tetap dimenangkan oleh pengusaha Prada Indonesia.

Jelaslah bahwa system first to file sebenarnya merugikan pihak pemilik merek pertama. Sebagaimana penulis contohkan diatas, bila ada sebuah perusahaan yang sudah memiliki merek terkenal disuatu Negara, misalnya Jepang, namun perusahaan tersebut belum terdaftar di Indonesia. Kondisi ini membuat pihak lain bisa mendaftarkan merek tersebut lebih dahulu ke Ditjen Hak Kekayaan Intelektual Departemen Hukum dan HAM di Indonesia. Dan jika suatu saat perusahaan dari Jepang tersebut ingin melakukan ekspansi di pasar Indonesia, maka perusahaan tersebut sudah pasti akan terganjal karena merek dagangnya sudah terdaftar terlebih dahulu atas nama pihak lain yang sebenarnya tidak berhak. 


\section{Merek Lebih Sering Menjadi Bahan Sengketa ke Pengadilan.}

Pengadilan Niaga Jakarta Pusat melansir sengketa Hak atas Kekayaan Intelektual (HaKI) yang sering bergulir di pengadilan adalah sengketa merek. Prosentasenya jauh lebih besar ketimbang perkara hak cipta, desain industri dan paten. Pengadilan mencatat, pada 2007 prosentase perkara merek sebesar $92 \%$ (67 kasus), hak cipta $2 \%$ (6 kasus), desain industri $2 \%$ (8 kasus) dan paten $4 \%$ (4 kasus).

Pada tahun 2009 Sengketa perebutan merek di Pengadilan Niaga sendiri juga menempati urutan teratas dibanding sengketa bidang HaKI lain. Pada 2009, ada 86 sengketa merek yang bergulir ke persidangan. Sengketa yang timbul malah melibatkan perusahaan antar negara. Salah satunya adalah sengketa antara Kenny Wirya dan Rocket Trademarks Pty Ltd. Perusahaan asal Australia itu mengklaim sebagai pemilik element, sedangkan Kenny pemilik merek Basic Element dan Element. Rocket Trademarks mengajukan gugatan pembatalan merek Element itu ke Pengadilan Niaga ${ }^{24}$.

Gambaran secara nasional juga menunjukkan banyaknya perkara merek dibanding bidang HaKI lain. Tengok saja data kasus yang ditangani tiga lembaga penegak hukum ini. Perkara merek yang ditangani Ditjen HaKI pada 2007 mencapai 29. Bandingkan dengan hak cipta yang hanya 9 kasus, desain industri 6 kasus, paten 3 kasus. Jumlah kasus merek pada tahun yang sama di Kejaksaan Agung adalah 32 kasus, dan ditangani Polri 83 kasus. Satu-satunya yang mampu mengimbangi jumlah kasus merek adalah hak cipta, itu pun lantaran banyaknya kasus VCD/DVD bajakan. Secara umum, merek lebih sering menjadi bahan sengketa ke pengadilan.

Mengapa perkara merek lebih sering disengketakan? Konsultan HaKI Suyud Margono menjelaskan pendaftaran merek bertujuan untuk membedakan jenis barang dan jasa sejenis. Merek itu bisa mengidentifikasi asal usul barang dan jasa. Untuk mempertahankan nama dagang tertentu, dipromosikan dengan mengeluarkan dana yang tak sedikit. Bahkan dari satu merek bisa berkembang beberapa desain industri dan paten baru. Terlebih lagi jika merek itu diambil dari

\footnotetext{
${ }^{24}$ Ibid.
} 
nama perusahaan. Jadi kalau dibatalkan atau diganggu gugat pihak lain akan menimbulkan kerugian secara bisnis, ujar Suyud saat dihubungi beberapa waktu lalu.

\section{Macam-macam Pengalihan Hak Atas Merek Terdaftar}

Hak atas merek merupakan hak khusus yang diberikan oleh Negara kepada pemilik merek terdaftar. Karena itu, pihak lain tidak dapat menggunakan merek terdaftar tanpa seizin pemiliknya. Hak ekslusif atas merek yang diberikan oleh negara kepada pemilik merek terdaftar memiliki jangka waktu tertentu. Jangka waktu tersebut dapat digunakan sendiri oleh pemilik merek atau dapat memberikan izin kepada pihak lain untuk menggunakannya.

Dari pengertian ini, agar suatu merek dapat dilindungi, merek tersebut harus didaftarkan. Pendaftaran merek diawali dengan permohonan pendaftaran merek. Permohonan adalah suatu permintaan pendaftaran yang diajukan secara tertulis kepada irektorat Jenderal HKI. Permohonan pendaftaran merek dapat diajukan oleh orang atau badan hukum.

Pengalihan hak atas merek terdaftar merupakan suatu tindakan pemilik merek mula-mula untuk mengalihkan hak kepemilikannya kepada orang lain. Pasal 40 ayat (1) Undang-Undang Nomor 15 Tahun 2001 menyatakan hak atas merek terdaftar dapat dialihkan karena:

a. Pewarisan;

b. Hibah;

c. Wasiat;

d. Perjanjian, atau sebab - sebab lain yang dibenarkan oleh peraturan perundang Undangan yang tidak bertentangan dengan Undang - Undang Merek.

Pengalihan hak atas merek terdaftar wajib dimohonkan pencatatannya pada Direktorat Jenderal Hak Kekayaan Intelektual dengan disertai dokumen yang mendukung. Jika pencatatan tidak dilakukan, pengalihan hak atas merek tidak berakibat hukum kepada pihak ketiga.

Hal ini sesuai dengan prinsip kekuatan berlaku terhadap pihak ketiga pada umumnya karena pencatatan dalam suatu daftar umum ( registrasi ).62 Pasal 41 
Undang - Undang Nomor 15 Tahun 2001 mengemukakan bahwa pengalihan hak atas merek terdaftar dapat disertai dengan pengalihan nama baik, reputasi atau lain - lainnya yang terkait dengan merek yang bersangkutan. Pasal 42 Undang Undang Nomor 15 Tahun 2001 menyatakan bahwa Pencatatan pengalihan hak atas merek terdaftarhanya dapat dilakukan bila disertai pernyataan tertulis dari penerima pengalihan bahwa merek tersebut akan digunakan bagi perdagangan barang atau jasa.

\section{Kesimpulan}

Dalam Pasal 3 Undang - Undang Nomor 15 Tahun 2001 disebutkan, hak merek diberikan kepada pemilik merek terdaftar, dengan demikian jelas bahwa sistem merek yang dipakai di Indonesia adalah sistem konstitutif (aktif) sehingga pemilik merek terdaftar adalah sebagai pemegang hak merek. Pemilik merek terdaftar sebagai pemegang merek menggunakan merek itu sendiri atau memberi ijin pihak lain menggunakannya.

Namun kedepan perlu untuk dicermati bahwa, perlindungan hukum atas kepemilikan sebuah merek harus di berikan secara menyeluruh di seluruh Negara. Artinya, apabila ada sebuah merek yang didaftarkan disuatu Negara, maka hendaknya merek tersebut juga dilindungi dinegara lain. Karena banyak pendaftar merek terkenal yang tidak memiliki itikad baik dengan membonceng merek yang sudah terkenal.

Masih banyak kasus-kasus pendomplengan atau pembajakan merek yang terjadi di Indonesia. Bagi Indonesia, tentu saja kasus-kasus serupa tidak harus terus terjadi. Karena bagaimanapun pemakaian merek orang lain dapat mempengaruhi citra merek yang pertama. Dapat menyesatkan konsumen karena konsumen akan mengira bahwa produk itu berasal dari produsen yang sama. Dari segi ekonomi, pemilik merek menderita kerugian akibat penjualan produk-produk palsu. Pada akhirnya konsumen tidak mempercayai lagi kualitas merek yang sesungguhnya. Perbuatan tersebut tentu tidak dapat dibenarkan karena membonceng ketenaran merek orang merupakan perbuatan melawan hukum. 
Dari itulah, sebagaimana telah diuraikan diatas, bahwa begitu banyak merek terkenal yang didaftarkan oleh bad applicant (pendaftar beritikad buruk) masih lolos terdaftar di Ditjen HaKI.

Menurut konsultan Hak Kekayaan Intelektual, Suyud Margono, Bad applicant, biasanya berlindung di balik asas first to file. Azas itu memberikan perlindungan hukum bagi pendaftar pertama. Kebanyakan bad applicant mendaftarkan ke kelas yang bukan eksention dari bisnis dimana merek tersebut berasal.

Pengacara spesialis HKI, Ali Imron, menyatakan banyak orang Indonesia mendaftarkan merek meski tidak berbisnis. Yang penting mereknya dulu, usahanya belakangan. Bahkan ada orang yang berprofesi sebagai pedagang merek. Ia menerangkan bad applicant mendaftarkan merek karena terinspirasi dari merek di luar negeri.

Dari hasil plesiran di luar negeri itu bad applicant mengetahui merek-merek asing. Kalau setelah dicek di Indonesia merek itu belum terdaftar, maka merek asing itu pun didaftarkan atas nama bad applicant. Jika suatu ketika pemilik merek itu datang ke Indonesia, maka pemilik merek yang asli tersebut tidak bisa memakai mereknya sendiri, tinggal negosiasi berapa mau beli merek bad applicant itu.

\section{Saran}

Akhirnya, konsep dasar pemberian hak atas merek adalah bahwa merek termasuk obyek hak kekayaan intelektual di bidang industri. Disamping itu, merek, sebagai hak milik yang lahir karena kemampuan intelektual manusia melalui daya cipta dan karsa, yang untuk menghasilkannya memerlukan pengorbanan tenaga, pikiran, waktu dan biaya, menjadikan karya yang dihasilkan tersebut mempunyai nilai.

Nilai ekonomi yang melekat pada hak milik itu menimbulkan konsepsi kekayaan (property). Dengan konsep kekayaan, maka HKI memberikan perlindungan hukum terhadap hak atas merek. Pemilik hak perlu dipertahankan 
eksistensinya terhadap siapa saja yang menggunakannya tanpa ijin. Merek tanpa sertifikat pendaftaran tidak akan dilindungi oleh undang-undang HKI.

Kedepan pemerintah dalam hal ini Ditjen Hak Kekayaan Intelektual Departemen Hukum dan HAM perlu kiranya mengambil langkah - langkah tegas. Atau menyiapkan aturan - aturan baru untuk melindungi merek seseorang atau pihak tertentu, terutama berkaitan dengan sistem hukum pendaftaran merek. Misalnya pendaftaran merek cukup dalam satu negara. Artinya, merek tersebut mendapat perlindungan dinegara manapun meski tidak didaftarkan. Yang tidak kalah penting, pemerintah harus segera menuntaskan revisi atau amandemen atas UU No. 15 Tahun 2001 tentang merek. Terutama terkait pasal-pasal yang sering menjadi perdebatan. Poin diatas penting, agar citra Indonesia sebagai salah satu negara pelanggar HaKI (hak atas kekayaan intelektual) di dunia bisa berubah dimasa-masa mendatang.

\section{Daftar Pustaka}

AB Susanto dan Himawan Wijanorko, Membangun Merek Unggul dan Organisasi Pendukungnya, Jakarta : Mizan Pustaka, 2008

Herdwiyatmi, Melingungi Citra Merek Melalui Pendaftaran Merek, Jakarta : DIRJEN Hakio, Jakarta, Juni-Juni 2009.

Haris Munandar, Mari Mengenal HaKI, Jakarta : Erlangga, 2009.

Hukum Online, Biaya Siluman di Balik Pendaftaran Merek, Selasa, 27 April 2007.

Hak Atas Kekayaan Intelektual Suatu Pengantar, Bandung : Alumni, 2002

Prayudi Setiadharma, Mari Mengenal HaKI, Jakarta : Goodfaith Production, 2010.

Suyud Margono dan Lingginus Hadi, Pembaharuan Perlindungan Hukum Merek, Novirindo Pustaka Mandiri, Jakarta, 2002.

Sudargo Gautama dan Rizawanto Winata, Hukum Merek Indonesia, PT,Citra Aditya Bakti, Bandung, 1993.

Tim Lindsey, et el, Hak Atas Kekayaan Intelektual Suatu Pengantar, Bandung : Alumni, 2006 
Taryana Soenandar, Perlindungan HAKI Dinegara - Negara Asean, Jakarta : Sinar Grafika, 2007.

Tribun Timur, Pengertian Merek 10 Desember 2009.

Venantia Sri Hadiarianti, Hak Kekayaan Intelektul : Merek dan Merek Terkenal, Jakarta : Unika Atma Jaya, Edisi Mei-Agustus 2009

Undang - undang No. 15 tahun 2001 Tentang Merek

www.patenindonesia.com

Wolfhard.Eric, International Trade in Intellectual Proerty : The Emirging GATT reginer University on Toronto Facultyt of Law Review, Vol 49 Winter (1991) : h: 107 